\title{
СТЕПАН РУДАНСЬКИЙ - МАЙСТЕР ЖАНРУ СПІВОМОВКИ: РОЗБУДОВА ІГРОВОЇ СТИЛІСТИКИ УКРАЇНСЬКОЇ МОВИ
}

\author{
ТЕТЯНА КОСМЕДА \\ Познанський університет імені Адама Міцкевича, Познань - Польща \\ STEPAN RUDANSKI - MISTRZ GATUNKI HUMORESKI: \\ ROZWÓJ LUDYCZNEJ STYLISTYKI JĘZYKA UKRAIŃSKIEGO \\ TETIANA KOSMEDA \\ Uniwersytet im. Adama Mickiewicza w Poznaniu, Poznań — Polska
}

STRESZCZENIE. W artykule omówione zostały cechy językowo-stylistyczne humoreski jako oryginalnego gatunku ukraińskiej kultury lingwistycznej, reprezentowanej przez lingwokreatywną działalność Stepana Rudanskiego. Przedstawiał on humor ukraiński na podstawie aktualizacji systemu środków językowo-stylistycznych, ujęzykowienia mentalności Ukraińców, ich kordocentryzmu, kultury śmiechu i in. Poetę słusznie można określić mianem mistrza rozwijania ludycznej stylistyki języka ukraińskiego.

\section{STEPAN RUDANSKIY, THE MASTER OF CHANTS: THE DEVELOPMENT OF PLAYFUL STYLISTICS OF THE UKRAINIAN LANGUAGE}

\author{
TETIANA KOSMEDA \\ Adam Mickiewicz Poznań University, Poznań — Poland
}

ABSTRACT. The article deals with the language-stylistic features of chants as an original genre of Ukrainian lingual culture that are represented in Stepan Rudanskiy's creative activity who managed to model Ukrainian humour based on the actualization of a system of language-stylistic means, verbalization of the Ukrainians mentality, their cordocentricity, laughing culture, etc. The poet can be easily considered the master of the development of the Ukrainian language stylistics.

„,Зародження мови слід шукати не в межах щчоденного, прозового, а в сфері життя поетичного. Джерело мови не сувора серйозність, а весела гра та радощуі здорової істоти..."

(О. Ссперсен)

\begin{abstract}
$\mathrm{C}$ тепан Руданський увійшов в історію української літератури й літературної мови пошевченківського періоду передусім як автор нового жанру співомовок. Письменник характеризує цей жанр як „гумористичносатиричний"1, такий, що $\epsilon$ вираженням закріплених у віршовій формі українських казок, легенд, приказок й анекдотів ${ }^{2}$. I. Франко порівнював зазначений жанр із коломийками. Образний прийом розгортання до цілих епізодів,
\end{abstract}

\footnotetext{
${ }^{1}$ В. М. Русанівський, Історія української літературної мови, Київ 2002, с. 237.

${ }^{2}$ Там само, с. 251.
} 
сюжетних ліній фольклорних алогізмів на зразок „на городі бузина, а в Києві дядько", відомий ще $з$ античності.

Живе мовлення українців зафіксовано в співомовках С. Руданського, для дискурсу яких характерна діалогічність, синтаксичні конструкції розмовного типу - неповні чи незакінчені речення, еліптичні конструкції, просторіччя, діалектизми, різні форми запозичень, вигукові елементи, відповідна стилістика - емоційні, експресивні, оцінювальні мовні одиниці, що виконують насамперед прагматичні функції.

Доцільно в цьому контексті актуалізувати міркування Ш. Баллі: „,. . що менш стійкі асоціації, засновані на фактах думки, то асоціації, що викликані формою слова або навіть його матеріальними, звуковими рисами, інтенсивніше прагнуть вийти на перший план у свідомості мовця"з. Справді, у свідомості кожного українця саме форма репрезентації думки, змодельована в співомовках С. Руданського, викликає асоціації насамперед із їхнім автором і стилістикою, характерною його поетичному дискурсу. Справжній талант і визначається тим, що його легко пізнають за формою діяння, у нашому випадку - дискурсу.

Співомовки мають, безперечно, ігрову природу. М. Гайдегтер писав, що поезія „нагадує гру, проте нею не є. Гра об'єднує людей, але в ній кожний забуває про себе. Тоді як в поезії людина зосереджена тільки на основах існування. При цьому вона досягає спокою; але не спокою бездумної бездіяльності, а спокою, що не знає меж, у якому залишаються живими всі сили й зв'язки"4.

Співомовки, або небилиці, належать до поетичних текстів, але їхня ігрова природа має глибші корені, оскільки вона грунтується на своєрідному характері сприйняття дійсності крізь приму ментальності українців, для яких характерно „сміятися крізь сльози” зі своїх вад, недоліків, скрутного становища і под. Сутність філософії саме такого ігрового сприйняття дійсності сфокусована в таких словах I. Канта: „Усяка мінлива вільна гра відчуттів (що не мають у своїй основі жодної мети) справляє втіху, бо вона посилює відчуття здоров’я, однаково, чи будемо ми в міркуваннях знаходити задоволення від його предмета і навіть від самого цього задоволення, чи ні..." . А Й. Гейзенга наголошує, що „поетична функція, народившись в ігровій царині, так i лишається в іії рамках" що виявляється в емоційно підвищеному, можливо, дещо несерйозному, із власними законами асоціювання, що далекі від узвичаєних правил мислення.

Гра реалізується як конкретний авторський задум. Ігровий характер співомовок - гра уяви, що дає змогу вийти за межі вузьких соціумних моделей, осягнути буття в ширших вимірах. Однак гра С. Руданського не завжди породжує комічне, вона може моделювати і так званий „чорний” гумор. Вочевидь, лікар С. Руданський був і добрим психологом, оскільки знав низку психологічних прийомів впливу на читача, які в розмаїтті моделював.

Г.-Г. Гадамер в „Основах філософської герменевтики” присвятив окремий підрозділ проблемі ігрової природи мистецтва. Він розуміє гру як „спосіб буття” твору мистецтва ${ }^{7}$, що й характерне для співомовок С. Руданського. Завдяки грі стає видимим те, що зникає чи не потрапляє до уваги за інших обставин.

${ }^{3}$ Ш. Балли, Франиузская стилістика, Москва 1961, с. 53.

${ }^{4}$ М. Гайдеггер, Гельдерлін і сутність поезї, [в:] Антологія світової літературнокритичної думки ХХ ст., за ред. М. Зубрицької, Львів 1999, с. 204-205.

${ }^{5}$ I. Кант, Естетика, Львів 2007, с. 172.

${ }^{6}$ Й. Гейзенга, Homo ludens, Київ 1994, с. 139.

${ }^{7}$ Г. -Г. Гадамер, Істина і метод, в 2 томах, Київ 2000, т. 1: Основи філософської герменевтики, с. $102-130$. 
Синонімічні назви небилиці - приказки-побрехеньки, співомовки: вже в цих номінаціях промовисто наголошено на лінгвістичному механізмі їхнього моделювання - "енергетичному потенціалі" абсурду чи алогізму, що в них зреалізований.

У термінологічному словнику тропів і фігур В. Москвіна запропоноване таке визначення абсурду: „Безглуздя, викликане неправдоподібною репрезентацією дійсності й алогізмом мовлення <...> Зумисний абсурд використовують як прийом $<\ldots>$ сатири, гумору, гротеску, іронії”⿱ . Натомість алогізм потрактовано як порушення логічного зв'язку в мовленні. Зумисний алогізм - фігура мовлення. У науковій літературі його називають „семантично невиправданим сполученням слів” - „каленим віником”. Алогізм пов'язують із актуалізацією категорії неймовірності (неправдоподібності). Л. Булаховський однак писав, що „для мовної правильності $€$ тільки один пробний камінь — фактичний ужиток... Але мова не є логічною: вона ... дозволяє найбільшій нісенітниці одягатися в граматично бездоганну форму..."10, що й продемонстрував С. Руданський.

Яскравим прикладом абсурду, вербалізації низки алогізмів $є$ співомовка “Вiр не вір, а не кажи: «Брешеш»”, яку й проаналізуємо. Як психологічний прийом у цьому разі використано аргумент до віри („Вір не вір”) ${ }^{11}$. Уже назва цієї небилиці налаштовує на ії жартівливе сприйняття, що стає зрозумілим із перших рядків: Народився я на світ, / Як їдного рання / Моя ненька забагала / Шиаків на снідання. / А я хлопещь-молодещь, / Пожалував мами, / Серед лісу відпитав / Дупло зі шпаками. У цьому контексті простежуємо й психологічний прийом впливу на читача у вигляді аргументаиії, скерованої до власних амбіцій, - лестощі, комплімент, похвала самого себе, що мотивована неймовірними, невірогідними вчинками, опис яких продовжується далі за текстом: $B$ дупло руку - не іде, / Голови не впхаю, / Сюди-туди по дуплі - Та й сам улізаю. / Ходжу голий по дуплі... / Шпаченят до ката! / Я в пазуху й загорнув / Тї̈ шпаченята. / Вилізати б, та не то!.. / Я й домудрувався, / Лиш сокиру притащив, / 3 дупла прорубався. / Гии із дуба на коня! / Кінь собі брикає, / А сокира моя все / Зад йому рубає. / Нагадався за сім миль, / Назад подивився, / А у коня, як на сміх, / Лиш перед лишився. / Давай тоді йому зад / 3 верби підправляти, / Як підправив, та й заліг / На годинку спати. / А кінь ходить по траві, / I перед пасеться, / А зад росте та й росте, / Аж до неба пнеться. / А для мойх шпаченят. / Того було й треба, — / Додряпались по вербі / До самого неба.... Наведений текст побудований на прийомі адінати - послідовного заперечення, що образно підсилено навмисною неправдоподібністю: перебільшення настільки велике, що виходить за межі можливого, $є$ неймовірним. Простежуємо активне вживання фразеологізмів, гру з ними, порівн.: Шпаченят до ката!; Щастя тілько, що святі / Не горшки ліпили, / Але якось на той час / Гречку молотили; За сім миль (повторюється кілька разів); Як на сміх; Того було й треба!; Та де вже, до ката!; Мені й горя мало!; Мамина дитина; Ну його з бідою!; Нечистая несе.

${ }^{8}$ В. П. Москвин, Выразительные средства современной русской речи. Тропы и фигуры. Общая и частная классификация, Терминологический словарь, Москва 2006, с. 39.

${ }^{9}$ И. А. Елисеев, Л. Г. Поляков, Словарь литературоведческих терминов, Ростов-наДону 2002, с. 8.

${ }^{10}$ Л. А. Булаховський, Мовознавство й логіка, [в:] Его же, Избр. труды, в пяти томах, т. 1: Общее языкознание, Киев, 1975, с. 140

${ }^{11}$ С. В. Рудан ський, Усі твори в одному томі, уклад. і авт. передмови Г. Латник, Київ: Ірпінь 2007. - Приклади для аналізу добираємо з цього видання (у дужках указуємо назву співомовки). 
Рефлексуючи на наукову метафорику Л. Булаховського, зауважимо, що ужита фразеологія належить до „гарячої, оскільки „«холодну» фразеологію маємо у людей освічених із зразковою літературною мовою.. $<\ldots>$ носії просторіччя говорять образніше й афективніше, ӥх мовлення пересипасться яскравими виразами, грубувато образними та емоційними. За цією манерою раз у раз звертатись до них для «приперчування» своєї думки ми відразу пізнаємо, до якої саме групи населення належить відповідна людина або якій вона внутрішньо симпатизує" (жирний шрифт авторський - Т. К.) $)^{12}$.

„Живе” мовлення С. Руданського, крім того, моделюється за допомогою вживання низки вигуків (Та не то!.. Гиц!; Гуттю-га!; Гоп!), що створюють ефект динаміки мовлення, швидкої зміни подій; вони вербалізують емоції та почуття. „...Ця афективна лексика нижчих кіл суспільства завойовує собі права як справжній шар дозволених у літературному вжиткові способів мовлення й задовольняє, серед іншого, потребу мови не стільки в збагаченні їі змістом, скільки збільшення стилістичної гнучкості"13.

У наведеному тексті кілька разів вжито іменник верба (Додряпались по вербі; Повертаю до верби! / А верба й пропала), що імпліцитно репрезентує смисл „неправда": цей смисл виокремлюємо на основі асоціації з паремією на вербі роcmymь груші, що репрезентує приклад адінати, є прецедентним феноменом.

Далі в цій небилиці алогізми аплікуються, наростають. Має місце амфігурія — прийом навмисного абсурду, що полягає в жартівливо-грайливому нагнітанні невірогідних фраз, порівн.: Ото уже я підріс, / Літ десяток було: / Дід ходив ще без штанів, / Батька ще не було; або далі: А ото вже дід niдpic / Та й $i$ одубився; / Після нього через рік / I батько родився.

Простежуємо також прийом комічного уточнення - уточнення, що створює ефект обманутого очікування, актуалізовано відповідну гру слів, що полягає в моделюванні тотожного смислу, імітації того, що думка змодельована по-іншому: То, бувало, коли хто / В гості запрошає, / То дід сяде на полу / Та ймене питає: / “А хто, — каже, — піде з нас?” / То я його гладжу: / "Та хто б, діду, не пішов, Все то їдн, —кажу. — / Або я туди піду, / А ви сидіть, діду; / Або ви собі сидіть, / А я туди піду”; або: А зимою холодно, / Нічим затопити, / То й питається дідунь, / "Що, — каже, — робити?” / "А щзо ж, — кажу, — тра комусь / Їхати в дубину!" / То, бувало, й каже дід; / "Хто ж поїде, сину?” / То я й кажу: "Хоч сидіть, / А я не поїду; / Хоч посиджу я за Вас, / А ви їьте, діду!'”; “А орати як зорем, / То вже чиє крашуе? / То не наше, а чуже, / То чуже, не наше".

Наведемо ще приклади деяких прийомів моделювання абсурду: типові зразки анахоризму, коли йдеться про те, чого не може бути: Тілько входимо у ліс, / Аж купа ломаччя! / Я сокирою гу-гуn! - Заєцьь з-під ломаччя. / 3-під ломаччя та у ліс. / "Гуттю-га!" На зайця! / Коли ми до тих ломач. / Аж там сиві яйия. / "Заберімо!" - “Заберім!” / Зважсили дрючками, / То насилу щзо згорнув / У шапку руками. / Ото я їх і приніс, / А в нас на ту пору / Розквокталася свиня, / Квокче коло двору. / “Пійми, сину!” — Я й піймав. / Посадив на яйця... / То ми мали з тих яєць / Шість волів від зайця.; Що як ото нам женців / Прийшлося збирати, / То безрукая їдна / Сама прийшла жати. / I нажала ж вона нам / Та кіп наскладала. / I стебла вже не було, / А та іще жала.

12 Л. А. Булаховський, Афективність і образність у соиіальному відношенні, [в:] Его же, Избр. трудығ.., с. 289-290.

13 Л. А. Булаховський, Афективне простомовлення, [в:] Его же, Избр. труды..., с. 363. 
Виокремимо деякі характерні моделірепрезентації абсурду, що актуалізовані в дискурсі поета: 1) заперечення часу та можливих дій в період його окреслення, а також умов реалізації певних дій, напр.: Народився я на світ, / Як їдного рання / Моя ненька забагала / Шпаків на снідання. / А я хлопець-молодець, / Пожалував мами, / Серед лісу відпитав / Дупло зі шпаками...; Ото уже я підріс, / Літ десяток було: / Дід ходив щее без штанів, / Батька щее не було; А ото вже дід підріс / Та й і одубився; / Після нього через рік / I батько родився. 2) алогізм дій і станів, неможливість наявності відповідних об' єктів чи суб' єктів, інтенсивності діiі, напр.: Кінь собі брикає, / А сокира моя все / Зад йому рубає. / Нагадався за сім миль, / Назад подивився, / А у коня, як на сміх, / Лиш перед лишився. / Давай тоді йому зад / 3 верби підправляти...; А кінь ходить по траві, / I перед пасеться, / А зад росте та й росте, / Ажс до неба пнеться...; Розквокталася свиня, / Квокче коло двору; 3) алогізм ознак, місця перебування, наприклад: В дупло руку - не іде, / Голови не впхаю, / Сюди-туди по дупліТа й сам улізаю. / Ходжу голий по дуплі...; То безрукая їдна / Сама прийила жати. / І нажала ж вона нам / Та кіп наскладала...; 4) невірогідна оцінка чогось, напр., часу: То внизу надточу. / I спускаюсь собі вниз. / Мало й остається, / Ще б урвати кілька раз, / А мотуз не рветься. / I висів я кілька літ...; 5) схожості з чимось, що невірогідне, напр.: І висохла, як дупло, / Моя середина....

Простежуємо й ігрову маніпуляцію омонімами чи паронімами, порівн.: Мати любить все парне, / А ми з батьком кисле. / Мати парить по селу, / А ми з батьком киснем; Купувати коли що — / Аж рука дрожала, / А як купимо - зато / Аж земля движала; I ото ж ми розжились, / Дві світлиці мали, / Світилося, куди глянь, / Лиш стовпи стояли!; Та ще потім по біді / I обід справляли..., А тепер ми розійшлись, — / Батько шинк тримати, / А я не так до шинка, / Як люблю орати. / Батько п'яний все держнить / За шинок рукою, / А я орю, як уп 'юсь, / Носом за кормою.

Співомовка „Вір не вір, а не кажи: «Брешеш»”, як бачимо, написана із виразним використанням гротескного стилю - навмисного неправдоподібного опису, основаного на фантастичному перебільшенні.

У співомовці „Гуменний” текстова гра побудована на розповіді, у якій інформацію про нещастя передано у формі омовлення факту нарощення проблем, градації — від проблеми зламаного ножа до смерті дружини й безчестя дочки, порівн.: Їздив дідич за гранищю, / Назад повертає, — Та й до свого гуменного / Листа посилає, / Щоб гуменний на границюю / Прибув $і$ дав знати, / Що діється в нього дома, / Да і коло хати. / Прибуває і гуменний: / „А щзо там Іване?” / А гуменний иому каже: / „Та все гаразд, пане. / Тільки ножик, щзо пан дали / Таляра за нього, / Поламався, сказать правду, / Ні з того ні з сього”. / „Ну зламався, так зламався, / I щзо й споминати. / Певне, хлопиі мали гратись / Та його зламали?” / „Таки правда, ясний пане! / Хлопці ізламали; / Лиш не грались, а сивого / Коня білували. ” / „А з чого ж то сивий згинув?” / „Пані хорували, / За лікарством як погнали, / Ті й і підірвали”. / „То і пані хорували? / Ах, Боже мій, Боже! / Що ж? Здорова моя пані? / Говори, небоже”. / „Помоліться, пане, Богу! / Лиш день хорували, / А на другий від пожару / Богу й душу дали!” і т. д. Прагнення гуменного делікатно подати негативну інформацію - від дрібних негараздів до великих проблем - створює ефект обманутого очікування.

У співомовці „Торбин брат” мовна гра грунтується на актуалізації та протиставленні двох змодельованих перифраз, відбувається заперечення аргументів, посилене створеними індивідуально-авторськими перифразами: 
Місяиь - братик Сонців, а мішок - торбин брат, порівн. контекст їхнього вживання: Докучило підшивати / Подертії сита, / Пішов циган молотити: / За торбину жита. / Пімов таки недалечко, - До свого сусіда... / От молотить та й молотить / Зрання до обіда. / Перекинув, може, з копу, / Хтів би й попоїсти, / Та господар, як на збитки / Не дає і сісти. / То наймита з ним поставить, / А то сам молотить. / Потягає бідний циган / Аж піт з нього котить. / Перекинув копи зо дві. / Ба, вже і смеркає. / „Чи не годі з нас, панотче?” - / Сірома питає. / I господар спочив добре / Та й до нього каже: / „Помолотим іще трохи, / Заким сонце ляжее”. / Знов молотить бідний циган, / Аж піт з нього котить, / Виглядає поза хату, / Ба, вже й місяць сходить. / Іскривився сіромаха, / Спину нагинас. / „Чи не годі з нас панотче?” - / „Або щцо?” - питає. / „Та щось, - каже, — не то світить?.. / Та ж то братик сонців!” / Коли братик - так і братик, / Нічого чинити; / Мусив бідний изиганюга / Всю ніч молотити. / На другий день той із хати, / А ииган у хату. / „A, здоровенькі, панотче! / Чи не можна б плату?” / „Можна, — каже, - чом не можна, / Як не дати плати? / Ходім, - каже, - до засіка, / Будем насипати". / Прийшов циган до засіка, / Торбу підставляє. / Пімов гарнець, пімов другий. / „Чи годі?” - питає. / „Насипайте іще!” - каже. / Сипле той і п'ятий. / Ба вже сипле і дев'ятий. / „Чи ж не годі, брате? ” / , Hi, не годі!”. Насипає / Цілу мірку жита. / Коли гляне - аж там торба / До мішка пришита. / Іскривився пан господар, / Голову схиляє. / „Чи не годі із вас, куме?” / „Або що?” - питає. / „А щось, - каже, — ваша торба / Та підчита чорним...” / „Підиитая?.. Насипайте!.. / Та ж то братик торбин!".

До ігрових засобів відносимо й поширений у співомовках прийом імітачії чужомовного акиенту, що виражається в порушеннях норм української мови, мотивованих інтерферентним впливом рідної мови комуніканта, напр., єврейської, що зображено в поезіях С. Руданського. Спостерігаємо й діалектні елементи мовлення, що аплікуються на інтерферентні, порівн. використання цього прийому в співомовці „Рабинова дума”: Далі рабин підійнявся: / „Стійте, - каже, - люде! / Послухайте, - каже, — люде, / Що то за страх буде! / Що то буде, як весь море / Стане їден море / I ӥден горою стане / Весь на світі гори, / I весь дерево на світі - / Дуб їен без міра / I сокира весь на світі - / Як їден сокира, / I весь люде, щуо на світі, / Які йно єсть люде, - Їден такий жид великий / Велика сокира, / Як на гора він зрубає / Такий дуб без міра, / I як з гора та на море... / Подумайте, люде!.. / Як великий дуб звалиться, — / Що то за хляп буде” чи у співомовці „Хто кого лучче?”: „А як же ви, Мошку, бились?” — / Хтось там запитався. / „Як ми бились? Та так бились, / Що світ дивувався! / Він на мене із ломаком / По плечах махало. / А я йому все з ярмарком / По носі давало!”. Далі в тексті цієї співомовки простежуємо апофізію - відхилення власної думки, щойно висловленої, порівн.: „Було з чого дивуватись!.. / А хто ж кого лучче?" / “Та Гаврило мене лучче, / А я його лучче!”.

Крім єврейського акценту, у співомовці „Рак” поет моделює й акцент німця, який говорить по-російськи (неправильне відмінювання й дієвідмінювання, порушення вживання родових і числових форм і под.), що також дає змогу створити комічний ефект: актуалізовано назву німецького одягу, на чому моделюється мовна гра - панцир рака порівняно з німецьким „кафтаном”, очевидно, спосіб його розміщення на фігурі людини асоціативно нагадує такий панцир: Забагає німець рака, / Не вміє назвати, / Закликає християнина, / Давай мудрувати: / „Вгадай, — каже, — что мой хочет?” / — „Та ні, не вгадаю!” / „Нога мно- 
га, уса долга! / Знаєш?..” - „Ні! Не знаю!” / „Как нє знаєш?.. Сам он малий, / Кафтан єго разний, / Как нє сварєн - кафтан чорний, / А как сварен - красний... / Тепер, — каже, —угадаєш?” / — „Та ні! Не попаду!” / „, Как нє знаєш?.. Шейка шльоп-ильоп, / А перед іззаду... ” / _ „Чи не рака? ” — „Рака, рака!'” / — „Бодай же вас, пане! / Найшли ж і ви в наших раків / Німецькі каптани!”.

Предметом мовної гри в С. Руданського стали й марковані суфікси -ськ(uй) i -овськ(ий), характерні для прізвищ поляків, що засвідчують їхнє шляхетне походження. Гра грунтується на факті модифікації прізвищ із утратою їхньої національної маркованості: марковані суфікси в польських прізвищах замінюються на національно маркований російський суфікс-ін. Для великодержавної ментальності росіян характерно все переробляти на свій манер, порівн.: Звісно, прізвиська в ляхів / На “-ський” та на “-овський”, / Але москаль, щцо діпне, / Верне по-московськи. / Ото колись москалі / Перепис складають; / Питаються двох ляхів: / „Как вас називают?” / Ото й каже їден з них: / - Јa - Раwlin Gruszecki. —A ja, — другий nidxопив, — Maryjanek Klecki! / Піши ж⿻ єво, — каже той: / Адін - Павєл Грушкін; / А другой... другой... другой... / Ну! - Мірон Галушкін!.. < .. > (Московська справа). Крім заміни суфікса, прізвище ще й перекладають за його внутрішньою формою (Klecki змінюють на Галушкін). У цій співомовці зафіксовано живий діалог: навіть процес міркування репрезентовано через характерне для комунікації (під час думання) повторення певного слова ... Адін - Павєл Грушкін; / А другой... другой... другой... / Ну! - Мірон Галушкін!.., що в поетичному тексті не завжди легко відтворити.

В окремих співомовках мовна гра мотивована актуалізацією зразка моделювання невдалої фатичної комунікації, як напр., у небилиці „Зелений пес”: Зайшов німець раз на баль, / 3 панною сідає, / Мовчить, мовчить, далі сам / Мову зачинає: / „, Чи зелений коли пес / Пані не здибала?” / „Та ні, — каже, або щзо?" - / Німияя запитала. / „, Та нічого, — каже той, - Я лиш так питався, / Бо з зеленим, пані, псом / I я не здибався!”. Значення лексеми зелений асоціативно пов'язане із смислом “невідомо”, що мотивоване асоціаціями, пов'язаними зі сприйняттям зеленого кольору в мовній свідомості українців, що, зокрема, актуалізованого і в ідіомі зеленого поняття не маю. У цьому контексті також репрезентовано польські лексико-граматичні мовні елементи (баль, панна, пані, зачинає, здибатися; Чи зелений коли пес пані не здибала?).

Письменник моделює мовну гру на основі вербалізації факту специфіки вимови звуків у різних мовах 3 актуалізацією звуконаслідування тварин, що простежуємо в співомовці „Кіт”: Несе м'ясо руський кіт, / Польський вихилясом: / „Що ти, котику, несеш?” / А той каже: „М'ясо!” / Та як “м'ясо” вимовляв, / М'ясо і упало, / I з ним польського кота / В минуті не стало. / Несе м'ясо польський кіт. / Руський і питає: / „Що ти, котику, несеш? ” / „, Міеsо! ”відвічає. / Та як “тіе̨sо” вимовляв, / То так стиснув зуби, / Що бідняка, руський кіm, / Лим облизав губи. Очевидно, тут маємо натяк на специфіку ментальності, типову поведінку відповідних народів. Виникає асоціація і з контекстом відомої української народної казки „Пан Коцький”, де нявчання кота відповідно семантизовано, декодовано.

На актуалізації вад вимови людини побудована співомовка „Глухий і багатий”, порівн.: Довелося на віку / Глухому з губатим / Раз у изеркві, на біду, / У парі стояти. / І губатий щцо почне / „Отченаш” читати, / То так губи іскладе, / Як ніби свистати. / Довго глухий поглядав. / 3 злості аж мінився, / Далі руку відвинув, / Ближче приступився / То по пиці його хвать: / „, Оm тобі 
— свистати!” / „Бог з тобою, - каже той, - / Бачим - я губатий!” / Але глухий другий раз: / „Дарма, щцо багатий!.. / У нас церква не на те, / Щоби в ній свистати!".

Омовлюючи табуїзми, С. Руданський також вдається до мовної гри, евфемізуючи їх, порівн. контекст зі співомовки „Війна”: Молотив раз у попа / Парубок Микита / Та якось там і украв / Цілу мірку жита. / Украв собі та й сховав. / Прийшло сповідатись — / Лихе його підвело / Попові признатись. / Лаяв, лаяв його nin, / Торгав за чуприну, / Наостаток і сказав: / „Отак, бісів сину: / Поки жита не буде, / Була б тобі трясия! - / Поти тобі не буде / Сповіді й причастя!"” / Ніщуо діяти!.. Вночі / Згорбився Микита. / Потихенько попід тин / Несе мірку жита. / Приніс якось до сіней — / Хату відчиняє, / Стає, бідний, у кутку. / Пари не пускає. / А попові на той час / Не Микита сниться: / Його сонна обняла / Тлуста молодиия. / Пробудився сонний піп, / Мацнув молодицю, / Підійма на жсивоті / Білую спідницю / Та й говорить: „Уставай, / Нічого дрімати, / Іде турок на війну — / Москву воювати”. / — „Та ваш турок не біда! / Каже чорнобрива, - / Коли турок хоче битись, / То Москва готова". / Що там було - звісна річ! / Кінчилося діло, / Аж Микита із кутка: „Кахи!” собі сміло. / Піп схватився: „Хто то там?” / — „Я, — каже Микита, — Отсе, - каже, - вам приніс / Вашу мірку жита”. / „А давно ж ти, каже піп, / До хати забрався?” / — „А давно! Ще на війну / Й турок не збирався!” / „Неси ж, —каже, — то назад / Та спожий, на щастя, / А я тебе взавтра й так / Пущу до причастя". Очевидно, має рацію Л. Булаховський, коли зауважує: „Не треба дивуватися, що значна кількість засвоюваних з масової мови лексичних елементів виконує протилежні функції; 3 одного боку, - огрубляти відповідні поняття, 3 другого, - правити як засіб завуальовувати непристойне, лише натякаючи на нього..."14.

Актуалізацію стилістичних девіацій, що призводить до моделювання двозначності, простежуємо в співомовці „Привітання”, зокрема йдеться про девіації щодо вживання зворотного займенника собі та репрезентації факту зустрічі батюшки через звукові реакції тварин, що створює комічний ефект: Наварив багач, напік: / Батюшку чекає. / Батюшка лиш на поріг — / От він і вітає: / „На тепленьке, в добрий час! / Тілько щзо зробили... / Та де ж то ви так були, / Батюшечко милий? / А тут тілько гавкне пес, / Свиня зарокоче, - / Та і думають усі, / Що то ви, панотче! / Спасибі ж, вам, що прийшли! / Пийте гріту з перием... / Ріжте собі печінки... / Крайте собі серие! / А заким то подадуть / Печеного зайия, / Не сидіте, прошу вас, / Лупіть собі яйия!”. Текст інтимізовано за допомогою використання зменшено-пестливих лексичних форм, що характерні для мовлення українців.

Моделювання лексико-семантичних девіацій створює комічний ефект і в співомовці „Просьба”, де простежуємо омовлену невідповідно зневажливу тональність, що стосується реліквій церкви: мовна гра побудована на номінації зображень святих, Божої Матері і Господа: Раз писали мужсики / До свого владики; / „Архирею, — пишуть, - наш! / Ясний та вельможний! / Церква наша з давніх літ / Перейшла нінащо / Кілько с у нас святих - / Всі стали ледащо. / Матір Божса на дошках / Згорбилась, зігнулась, / А постоли розійшлись / А Варвара здулась. / Миколай від хробаків / Порохом узявся. / Сам Спаситель на ватах / Поздовж перепався. / Миколая нам позволь / Наново зробити. / Матербожій через зад / Клин їден забити. / Апостолі всіх уряд / Дрючками

\footnotetext{
${ }^{14}$ Л.А.Булаховський, Афективне простомовлення..., с. 362.
} 
зігнати / Спасителя на вратах / Щоб на шиуги взяти. / А з Варварою уже / Нічого робити: / Коли вона здулась так, / То кажи покрити”. Текст містить низку вульгаризмів, що так чи так наявні в „живому” мовленні українців.

Наголосимо, що С. Руданський часто використовує побутові евфемізми й дисфемізми, напр.: Та й i одубився (“помер” — Вір не вір, а не кажи: „Брешеш”); Помоліться, пане, Богу! / Лиш день хорували, / А на другий від пожару / Богу й душу дали! ("померли" — Гуменний); Пийте гріту з перцем (“горілка" - Привітання); Пари не пускає (“мовчить"- Війна).

У співомовці „Там іiі кінець” своєрідно евфемізовано значення слова “хабар", порівн.: Архирей їден подольський / Такий звичай мав, / Як без грошей була просьба, / То ї̈ і не приймав. / Аж дяк якось коротенько / Просить стихаря, / А на білу середину / Кладе хабаря. / Архирей і не гадає, / Що там далі є... / Пробіг живо його просьбу / Та й назад дає. / Той і просить: „Прочитайте ж!” / — Та я прочитав! / „Та іще раз прочитайте!” / - Ще раз прочитав. / “Моя просьба на тім боці, / Там ії кінець!” / Аж тоді затримав просьбу / Святий панотець.

Евфемізація статевих стосунків священнослужителя із жінками приходу жартівливо вербалізована в співомовці „По старій печаті”: Вмерла жінка у попа / A nin хитриться, / Що до виводу прийде / Яка молодиия / То він ї̈ покрепить у хаті / Та і скаже, щзо то / По старій печаті. / Подобалась та печать / нашим молодицям.... Евфемізми систематично актуалізуються для моделювання відповідних еротичних смислів, порівн.: Із панною на печі / Кілька разів явся („Свята сім'я”), А сестра то, хоч мала, / Та вже давно трісла („І нє нахвалятса"), Іде турок на віну - Москву воювати. / - Та ваш турок не біда! - Каже чорноброва, - Коли турок хоче битись, / То Москва готова („Війна”).

Певна „неясність” тексту моделюється через спеціальне застосування мовної гри, дотепних навмисно організованих непорозумінь, що вимагає від читача певного „розплутування” смислу, за що читач отримує нагороду: своєрідну насолоду від сприйняття подібного тексту.

У співомовці „Штука” також репрезентовано кілька евфемістичних виразів, весь текст змодельовано на прихованості грубого вульгарного омовлення ситуації, порівн.: Біжить старий поза хлів, / Ногами дрібоче, / Уже його й не питай, / Чого то він хоче. / Тільки, тільки щчо прибіг, / За очкур вхопився... / Але закіль розпустив, / В итани вгаталився. / Почухався старий ярин: / „Най же твою матір! / Та такої штуки я б / Докачав $і$ в хаті!". Як бачимо, письменник репрезентує абстрактне значення лексеми “штука", яку можна зарахувати до системи узагальнено-кваліфікативних слів негативно-оцінної семантики ${ }^{15}$. Уживання подібної лексики для вербалізації негативної оцінки характерне для українського дискурсу ХІХ ст., зокрема цей прийом використовує й Т. Шевченко в его-текстах ${ }^{16}$.

Поширена в текстах співомовок й аномінація - різновид поліптору (повторення одного й того самого слова в різних відмінках), що інколи фразеологізується, напр.: А щзо ж люди? Та жид жидом („Рабин і запорожець”), зазначений прийом актуалізується в назві співомовки Свиня свинею - Ta свиня таки свинею! / Правду кажуть люди: / Святи ї̈, хрести ї̈-все свинею буде!. Цей прийом посилює репрезентацію смислу, що міститься в омовленому цими формами концепті.

${ }^{15}$ Див.: Т. Космеда, Аксіологічні аспекти прагмалінгвістики: формування і розвиток категорії оичнки, Львів 2000.

16 Див.: Т. А. Космеда Ego i Alter Ego Tapaca Шевченка в комунікативному просторі щоденникового дискурсу, Дрогобич 2012, с. 292. 
Комічний ефект створює й репрезентація мовлення служителів церкви, які використовують вульгарну, брутальну чи навіть лайливу лексику, пов'язану з вербалізацією нечистої сили на тлі загальної ввічливої тональності - простежуємо зіштовхування низького і високого як прийом мовної гри. Це, однак, типова риса мовлення священнослужителя, що засвідчують фольклорні тексти, зокрема й співомовки, порівн. дискурс поезії „Хто святив?”: Питається архірей / Попа молодого: / „Який, - каже, - тебе чорт / Висвятив, дурного” / А той йому, неборак, Глянув тілько в очі: / „Та святили ж, каже, — ви, / Пресвятий панотче!”. Фрагмент цієї співомовки ввійшов у систему прецедентних текстів української лінгвокультури.

У співомовці „Горох” змальовано також мовлення священика, який, засуджуючи інших за вживання у святому місці брутальної лексики, сам ії використовує, що й породжує комізм, порівн.: Розкипається горох, / Наймит - що діяти? / Іде в иеркву до попа / Обідати звати. / Розштовхуе мужиків / І сажею маже. / Піп якраз стойть з хрестом, / А той йому каже: / „Та ідітьбо на обід, / Годі з вас молиться: / Бо горох там на гівно / Далі розкипиться!" / „Тю на тебе! - каже піп. — / Чи встиду не маєш? В такім місці ти святім / Гівно поминаєи!” / Далі хрестом замахав: / „Геть від мене! - каже. - / Бо я тебе погівню, / Аж всерешся, враже”.

Степан Руданський досить активно залучає знижену, вульгарну лексику, що, утім, характерно для живого мовлення простих людей. Щоб відтворити реальну комунікацію, поет не завжди евфемізує брутальні вирази. Часто, як зауважувалося, він моделює конфлікт між високим і низьким, тобто актуалізує бурлескний стиль: Говорив раз піп казаня /Із письма Святого / „Чого, грішнику, так липнеш, - / Каже, — до земного? / Подивись на Божу птицю, / Як вона літає; / Ні оре, ні жне, ні сіє, / Ані пожинає". / А староста напереді / Тілько засміявся / Та до ключника старого / Стихача озвався: / -, Та якого ж⿻ каже, -чорта / Тая птиця й має?! / Скаче тілько по дорозі / Та гівна шукає" (,Божі птиці”).

Наведемо ще один яскравий приклад, що ілюструє висловлену вище тезу. Назва співомовки „Ов!” - це субстантивація вигуку, що містить виразну прагматику, експліковану в тексті. Цей вигук - мовний засіб національно специфічної вербалізації почуттів, оскільки такого вигуку немає в інших, навіть слов'янських, зокрема і в російській, лінгвокультурах. Говорив піп на казанні: / ,Було-то собі, - каже, гай, / За тим гаєм - ще гай, / А за ним - іще гай!.”. У наведеному контексті змодельовано бделігму - беззмістовний перерахунок (такою $є$ інформація про гай). Оповідь починається типовим зачином, що характерний для української народної творчості, зокрема казки: ужито частку собі, яка актуалізує інформацію про ментальність українців - прагнення до самостійності, окремішності, порівн. із типовим російським зачином, характерним для російських народних казок, де не вживають цю концептуальну частку: „Жили-были дед и баба...”. Тут немає вказівки на бажання бути самостійним, відокремитися, відчужитися.

Далі в співомовці „Ов!” стверджується: „Там-то, - каже, - святий Юрій / Показав своє добро, / Як пришпилив змію люту / Та списою під ребро. / То змія вже і почула, / Що тут ї̈ буде смерть: / Лягла тілько, протягнулась / Та все собі пердь та пердь! / А староста: „Ов, панотче!" / Ажс узявся за чоло. / Мабуть, йому таке слово / Не до думки підійшло. / A піп йому: „Не «ов", дурню! /Бо щцо правда - то не див! / А ти, старий, аж би всрався, / Що б тебе так 
пришпилив!”. Як бачимо, субстантивуючись, вигук набуває, крім прагматики, ще й відповідний смисл. Вульгарна лексика омовлює ситуацію розмовного мовлення, хоч, як показано, не всі носії української мови полюбляють використовувати вульгарну лексику.

Крім того, у цій співомовці простежуємо вплив польської мови, що виявляється в актуалізації граматичної форми жіночого роду (замість чоловічого) в лексемі спис (...Tа списою під ребро...) і лексико-граматичної форми лексеми див замість диво (... Бо щзо правда - то не див!...), що мотивовано польською формою cud - аналога української лексеми чудо.

Для моделювання „живого” мовлення С. Руданський активно застосовує прийом актуалізації діалогічного мовлення. Для репрезентації зазначеного наведемо й дискурс співомовки „Чого люди не скажуть!”: Не вважає архірей, / Що й сам не без того, / А бештає за гріхи / Вдівия молодого. / „Хто сказав вам?” - каже той. / „Як то хто? А люди!” / „Та хто тепер людям тим / Вже вірити буде?!” / „Та вже вони і вас, / Пресвятий панотче, / Розказують то і то... / Звичайно, не в очі!” / Здихнув бідний архірей. / „Іди ж, - каже, з Богом!" / Та ще й хрестом наділив / Вдівия молодого. У цьому разі С. Руданський вербалізував комунікативному тактику, що застосовується й сучасними українськими політиками в їхній риториці, яка отримала номінацію „переведення стрілок” - переадресація негативної інформації зі своєї особистості на особистість свого опонента.

Як бачимо, хоч теорія комунікації на той час не була розроблена, але С. Руданський відтворював iі постулати, зокрема в співомовці „Свічка” поет репрезентує один із важливих законів комунікації, що має назву закон спотворення інформації (,зіпсований телефон”), порівн.: Купив свічку раз купецьь, / Подає другому / Та й говорить з-за плечей: „, Сегєю святому” / А наш собі не дочув - / Подає другому / та й говорить з-за плечей: / „, Андрєю святому”. / Пішла свічка по руках, / А той поглядає: / Ото староста вперед / 3 нею наступає. / До Андрєя просто йде, / А той не звинеться: / Поміж лди наперед / Собакою рветься! / „Да какому, - закричав, - / Лєпіш дуралєю? / Нє єнтому, гаварят! / Гаварят, Сергєю!”.

У співомовці „Мало не ригаю” відтворено закон комунікативного самозбереження, зреалізований прийомом відхилення негативної інформації під загрозою іiі критики або заперечення, з метою нейтралізації негативної оцінки, критичного ставлення до себе з боку співрозмовника. До речі, така мовна поведінка також властива сучасним українським політикам. Письменник знову майстерно моделює „живий” діалог, порівн.: Питається архирей / Батюшку старого: / „Чув я, - каже, - щзо ти n'єш / Багато хмільного” / „Не вірте, 一 каже той, - Хіба тілько воду, / А хмільного - свідок Бог - / Не кушаю зроду”. / „Не кушаєш” - каже той. - / Зроду не вживаєш?” / „Як же ж, — каже, ти вино / 3 чаші випиваєш?” / „Не питайте! — каже піп. - Пити - випиваю, / Але сам я - свідок Бог / - Мало не ригаю!’. У цій співомовці використано психологічний прийом аргумент до віри, а гумористичний ефект виникає ще й від того, що у свідки бере собі священик самого Господа, порушуючи заповідь не звертатися до Бога в суї. Знову моделюється абсурдна ситуація.

Подібну комунікативну тактику зображено і в співомовці „Циган на сповіді", де комунікант маніпулює словами, неправдиво окреслюючи реальну ситуацію, що нейтралізує іiі негатив, характеризує власні злодійські вчинки так, що в його устах вони набувають позитивного забарвлення, порівн.: Раз задумав 
ичганчук гріха сповідати, / Іде просто до попа. / Приходить до хати. / Оглядає - ні попа, / Ні слуги Бог має, / А в горосі, у печі / Сало закипає. / Циган сало із горика, / Живо із пекарні, / Через цвинтар позадгузь / Та й до паламарні. / В паламарні, як на гріх, - /Шапка на кілочку; / Він і шапку потягнув, / Сховав у куточку / Та й годі вже до попа / Гріхи сповідати. / Ото піп йому дає / Хреста иілувати. / Поиілував циганчук; / Піп його питає, / А той йому всі гріхи / I оповідає: / „, Та й сьогодні, — каже, — / Нагрішив потроху: / Ранком вигнав я свиню / 3 чужсго гороху. / А у церкві шапку зняв!.." / Говорить несміло. A nin йому: „То не гріх! / To добреє діло!” / „Добре, добре, нехай так, / По «Буди господнє»". / Піп до шапки, — але ба! / І місце холодне... / Піп - додому, до горика - / А сала не стало. / І промовив старий піп: /„Оже же признавався! / А я старий та дурний, / І не догадався!".

В українську лінгвокультуру С. Руданський увійшов як „сміхотун”, майстер моделювання гумору, сатири, жарту, абсурду. Очевидно, це йому так добре вдавалося насамперед тому, що письменник був людиною веселої вдачі попри всі життєві негаразди.

Способи створення комічного традиційно відносять до числа психологічних прийомів, які активно використовує поет: простежуємо вербалізацію двох видів смішного: 1) смішне в словах і 2) смішне в предметах — смішні історії. Вербалізовано категорію неймовірного, зреалізовано стиль навмисного неправдоподібного опису, що базується на фантастичному перебільшенні ситуації, яка доводиться до абсурду; яскравим вираженням цього є система алогізмів, реалізована через низку прийомів: заперечення, що образно підсилене фантазією, яка зростає до неправдоподібності; гіперболізацією, у якій перебільшення настільки посилене, що виходить за межі можливого; жартівливо-грайливе нагнітання невірогідних або алогічних за змістом словосполучень чи фраз, оксюморону, каламбуру на основі актуалізації та зіткнення різних значень багатозначних слів, омонімів чи паронімів, протиставлень; припущення навмисних неточностей; наведення абсурдних уточнень; трансформація паремій, їхня контамінація; моделювання образних перифраз; заперечення аргументу, посилене смішним порівнянням; натяк; актуалізація оригінальних перифраз; парадоксальні судження; відхилення думки, яка щойно висловлена; приховане повчання, виражене антитезою; позитивна оцінка під виглядом негативної; раптове зниження стилю мовлення; конфлікт між низьким і високим; беззмістовний перерахунок деталей, що доводиться до абсурду; використання побутових евфемізмів; дисфемізмів; нагнітання вульгаризмів; евфемізація побутових табуїзмів; використання макаронічного мовлення для створення національного колориту, іншомовного акценту і под.

Степан Руданський постає перед нами передусім як майстер моделювання світлого гумору. Використовуючи систему мовних засобів, він розбудовує українську ігрову стилістику, продовжуючи традиції, закладені його попередниками. Як Іван Котляревський чи Микола Гоголь, Степан Руданський творить позитивний, високий сміх. Цей сміх пронизує, власне, структуру його мовлення. Сміхове організується так, що негативні явища репрезентуються як один із аспектів реальної української дійсності. Слово поета розкриває й табуйовані смисли, що не завжди $є$ пристойними 3 огляду на високу мораль і культуру. Це також лежить в основі механізму створення сміхового ефекту, розбудови сміхової лінгвокультури. У процесі акумуляції й розширення значення слова різного типу конотаціями, актуалізації національної прагматики, С. Руданський 
використовує багатошарову тканину української мовної стихії, яка покликана боротися з усім, що робить мову мертвою й закостенілою.

„Живе” мовлення українців змодельоване письменником надзвичайно правдиво. Він репрезентує типові комунікативні стратегії й тактики українців і щодо нейтралізації негативу, і щодо створення інтимної атмосфери, і щодо самореклами, самопрезентації, нейтралізації конфлікту, зокрема й шляхом актуалізації гумору, алогізму, абсурду; передає уміння українців „скидати” негативні емоції за допомогою проклять, вигуків, системи дискурсивних слів, уміння сміятися 3 себе.

Письменник репрезентує українську ментальність, що виражається у „високій емоційній температурі мовлення”, кордоцентризмі, доброзичливому ставленні до довкілля, виявленні релігійних почуттів, однак без фанатизму, щирій гостинності, прагненні до самостійності й незалежності і под.

Існує думка, що „велика” i, разом із тим, „важка” за своєю будовою фраза (ширше - мова, мовлення, дискурс) виникла з особливостей „важкого характеру" певних народів - носіїв відповідних мов, як i, навпаки, у народів життєрадісних історично зростає як вияв їхнього „духу” „легка” мова, що стає ознакою лінгвокультури загалом.

С. Руданський довів, що українська мова є „легкою”, необтяженою важкими конструкціями, складними формами вербалізації думки, а українці належать до народів життєрадісних, легкодумних, хоч інколи на їхній оптимізм накладається і світла печаль, гіркий смуток.

Легкість стилю, здатність моделювати „сміх крізь сльози” продемонстрував і Микола Гоголь, хоч писав він російською, але ж у його мовленні було відбито українську ментальність, він репрезентував лінгвокреативність, актуалізуючи особливості українського національного характеру, що втілений у „дух” української мови, є складовою структури української мовної особистості, адже „національне пронизує всі рівні мовної особистості"17, тому скільки б не твердили, що М. Гоголь - російський письменник, однак „дух” його мовлення репрезентує українську ментальність, хоч і засобами іншої мови, яка, однак, характеризується егоцентризмом українізмів. Мова однозначно $є$ „засобом трансляції менталітету між поколіннями лінгвокультурної спільноти"18, що яскраво продемонстрував і Степан Руданський.

${ }^{17}$ Ю. Н. Караулов, Общая и русская идеография, Москва 1990, с. 42.

18 В. Н. Телия, Номинативный состав языка как объект лингвокультурологии, [в:] Национально-культурный компонент в тексте и в языке, в 2 частях, Минск 1994, ч.1, с. 15. 